\title{
Visuelle formidlingsformer
}

\author{
af Preben Breds
}

Titlen på dette essay er en ret så løs formulering af dets emne. Det er rimeligt at forudsætte, at disse formidlingsformer har relation til idræt og idrætshistorie. Alligevel kan det synes nyttigt først at gøre nogle overvejelser over visuel formidling generelt.

Når emnet her er formidling af visuel art, synes det tilstrækkeligt at fastslå, at der er tale om henvendelser til øjet. Men det er en sandhed med modifikationer, for det er af afgørende betydning af hvilken art denne øjenhenvendelse er.

\author{
Skrift \\ er jo strengt taget \\ en visuel meddelelsesform, for \\ så vidt som den indtages gennem øjet. \\ Alligevel stilles skrift og billede al- \\ mindeligvis over for hinanden som et modsæt- \\ ningspar, hvoraf kun billedet regnes for at væ- \\ re visuelt (og sådan vil ordet ,,visuel" da også \\ for nemheds skyld blive brugt senere i dette essay.) \\ Skellet mellem de to udtryksformer er et skel mellem \\ verbal og ikke-verbal meddelelse, hvilket \\ imidlertid er en afgørende forskel i psy- \\ kologisk og erkendelsesmæssig henseen- \\ de. Skriften skal en omvej ind over \\ sprogcentret $\mathrm{i}$ hjernen for at blive \\ afkodet, mens billedet ,,går lige \\ ind". Man hævder, at et \\ billede siger mere end \\ tusind ord, men det er \\ en skødesløs iagttagel- \\ se. Den væsentlige for- \\ skel er snarere, at billedet \\ siger noget andet end ord.
}


Den nyeste videnskabelige indsigt $i$ de to hjernehalvdeles funktionsmåde giver en vis forståelse for den grundlæggende forskel i opfattelsen af verbale og billedlige formidlingsformer. Et par ord herom:

Hjernehalvdelene behandler informationer på vidt forskellige måder. Den venstre halvdel, hvor sprogcentret normalt befinder sig, arbejder analytisk og sekventielt, dvs. i små bidder, den ene efter den anden, og kan kaldes computeragtig. Den højre halvdel arbejder holistisk, dvs. i øjeblikkelige og totale erkendelser, billed-og mønsteragtig.

Set i sammenhæng med visuelle formidlingsformer er det en oplysende konstatering, at skrift og billede $\mathrm{i}$ store træk altså henvender sig til hver sin hjernehalvdel, og at de formidlede budskaber bearbejdes på hver sin måde. Det skal dog tilføjes, at denne simple opdeling kompliceres ved forskellige krydsninger. Således kan et billede f.eks. bearbejdes analytisk og sekventielt og skrift kan være en ,blomstrende billedlig tale“, som fremkalder forestillingsbilleder.

Dette grove rids af disse fænomener skal imidlertid kun tjene til at henlede opmærksomheden på litteraturen om dem, da emnet er for krævende til at kunne fremstilles rimeligt af en amatør.

I vurderingen af skrift over for billede som formidlingsform indgår også nogle kulturelt betingede værdinormer af historisk oprindelse. Som bekendt har der $\mathrm{i}$ århundreder været en tendens til at foragte billedet lige så meget som bogen har været i højsædet. Billeder har været og er for børn og analfabeter, mens de lærde og skolelærerne har set ned på og bekæmpet denne enfoldige formidlingsform.

Det kan jo ikke undre kristne mennesker, som naturligvis kender Guds ord til Moses fra de 10 bud, hvoraf det andet lyder: „Du må ikke gøre dig noget udskåret billede eller noget afbillede af det, som er oppe i himlen eller nede på jorden eller i vandet under jorden."

Jøderne blev „Bogens folk" og fuldstændig billedfjendsk. Med kristendommens sejr i romerriget opstod konflikten mellem ordet og billedet. I perioder blev billedet forfulgt (de såkaldte billedstorme, hvoraf en udløber raser i dagens pornodebat), men det overlevede. Dets prestige derimod faldt dybt, idet det mistænktes for i sit væsen at være usædeligt hedensk. Selv om billedet med tiden antog fromme former, kunne det dog aldrig måle sig med bogen, Biblen, Guds ord.

Billedet var for den vulgære hob, skriften for præster og lærde, en spaltning af visuelle formidlingsformer $i$ to kulturer, som trods skoler og demokrati kan skelnes den dag i dag.

Den førkristelige oldtidskultur, specielt den klassisk græske, vidner om, at denne værdiansættelse af skrift og billede ikke er naturgiven. Mig bekendt har ingen vovet at kalde den primitiv eller anti-intellektuel, og dog spillede 
skriften dengang en ganske underordnet rolle. Atheniensernes børn gik $i$ skole, og læsning og skrivning var almindelige færdigheder. Alligevel var kulturen først og fremmest en mundtlig- og billedkultur. Grækerne var et usædvanlig visuelt begavet folk, hvilket de overleverede vasemalerier, den fremragende tempelarkitektur og de uovertrufne statuer af guder og atleter beviser. Den græske skulptur og arkitektur var ikke „,pæn“ eller „,smart“, dekoration eller pomp, nej, de var udtryk for en højt raffineret intellektuel kultur. Bag bestræbelserne i deres udformning lå en geometrisk analytisk virksomhed for at finde frem til de ,rette" proportioner, en kanon, der skulle være i harmoni med deres geometriske opfattelse af verden, og således på een gang være både skøn og sand.

Vi har lært at beundre deres frembringelser, men vi er ikke i stand til at „se" stenenes intelligente udtryk, før vi har læst en bog om det.

Tag en visuel udtryksform som et græsk tempel. Øjet omfatter og fatter det i eet nu - det er overskueligt. Konstruktionen er synlig og umiddelbar logisk forståelig.: Søjlerne bærer faktisk bygningen, taget hviler på overliggerne og disse igen på søjlerne. Det er funktionalisme. Øjets indtryk af bygningen er sand og den synes harmonisk og skøn. Et tempel som Parthenon demonstrerer, hvorledes templet blev opfattet som en visuel meddelelse - det blev bygget til øjet: I virkeligheden står søjlerne ikke lodret, men hælder således, at de for øjet ser ud til at stå lodret, hvorved budskabet om sand orden og harmoni har fået synligt udtryk.
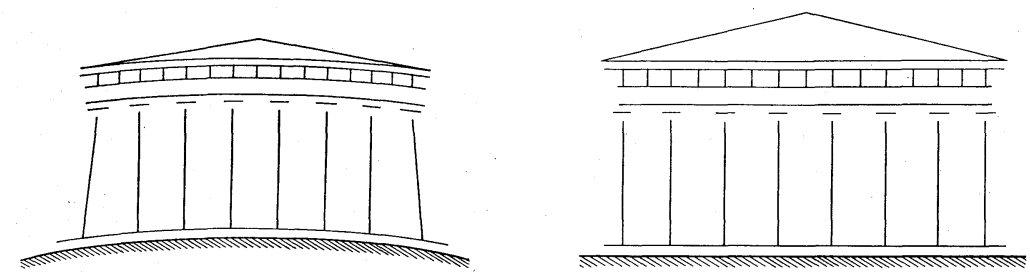

Mens græsk intelligens $\mathrm{i}$ høj grad udtrykte sig visuelt er intelligensen $\mathrm{i}$ vor kultur i lige så høj grad gået „,den boglige vej" med en udsultning af billedkulturen til følge.

For at gøre ondt værre har de boglærde tilmed udviklet flere special-sprog, som fuldstændig afskærer den jævne mand fra indsigt. Denne form for sprogligt hemmelighedskræmmeri har oven i købet fået så stor prestige, at billedkunsten har fulgt eksemplet og frembragt de mange ,-ismer", som kun de indviede kan forstå og værdsætte. Manden ,,på gulvet" må nøjes med at klø sig i sit rindalske hoved.

Når man gør sig overvejelser over de visuelle formidlingsformer, synes det på denne baggrund vigtigt, at se på til hvem formidlingen skal henvende sig. 
Af de ovennævnte historiske grunde fremgår det, at vort uddannelsessystem i særlig grad bygger på den venstre hjernehalvdels specielle bearbejdningsmetode med skriften i centrum. Ikke desto mindre anslås det, at der $\mathrm{i}$ dagens Danmark findes ca. 3/4 million mennesker, som har problemer med at læse, de såkaldte ,funktionelle analfabeter". Det bør måske understreges, at de ikke nødvendigvis er „,dumme“, men deres intelligens kan f.eks. ligge uden for sprogligt domineret kultur. Sammen med den gruppe, som Poul Henningsen kaldte analfabeter, der har lært at læse, er der tale om en ganske stor del af befolkningen. Selvsagt er det ikke disse mennesker, formidlingen udgår fra. De skriver ikke bøgerne, kronikkerne, aviserne osv., og de er heller ikke oplagte modtagere af formidling gennem disse media. Billedet er deres medium, billedblade, tegneserier, film og TV. Omvendt findes der stadig dannede mennesker, der ikke har TV, fordi de har noget bedre at bruge deres tid på, bøger f.eks. Det er i høj grad de uddannede, dvs. bogligt uddannede, der skriver til hinanden i de seriøse media, og det er også dem, der er „kulturbærende“, dvs. dem der definerer ordet kultur, og som fordeler samfundets ressourcer på det kulturelle område. De billedbaserede formidlingsformer (her tænkes ikke på ,,finkunst") er således traditionelt blevet unddraget såvel økonomiske som intelligensressourcer, hvilket yderligere har uddybet skellet mellem de to formidlingsformer og de to kulturer.

Snot for sig og skæg for sig, som det hedder.

Idræt, defineret som bevægelse af kroppen, er karakteristisk ved at være synlig og altså velegnet til billedlig fremstilling. I sig selv kan den opfattes som en visuel formidlingsform, hvis en tilskuer ser aktiviteten som udtryk for særlige værdier som ynde, styrke, vilje osv. Kroppen selv kan anskues på samme måde, når betragteren $\mathrm{i}$ den ser udtryk for personligheden, egenskaber som slaphed eller karakterfasthed - ,en mand med rygrad “ - osv. I den forbindelse er det værd at bemærke, at idræt er blevet og bliver anvendt som et redskab til at fremelske ønskede egenskaber og måske navnlig skabe kropslige udtryk for dem: De græske atleters ideale skønhed - vor tids body-builderes umådelige styrke.

Det er imidlertid formidlingen af idræt, som interesserer nu. Idræt har altid haft sine tilskuere. Sagaerne såvel som Homer beretter om det, i ord. Grækernes kunstværker vidner desuden om idrættens centrale placering i deres kultur. Her er tale om en sammensmeltning af såkaldt ,åndelig“ og „kødelig“ kultur - idrætspladsen var et kulturcentrum, og formidlingen af kropslige værdier havde den højeste prestige i samfundet. I dag betragter vi de gamle værker som kunst, slet og ret, mens vor tids kunst beskæftiger sig med alt andet end idræt. Emnet mangler tilsyneladende kulturel prestige.

Ikke desto mindre har idrætten også i dag voldsom tilskuertække og stor interesse $\mathrm{i}$ befolkningen. Følgelig formidles den i stor stil via forskellige 
media.

Forstået som bevægelse formidles idræt selvfølgelig bedst ved hjælp af levende billeder, hvad enten de er på film eller elektroniske. ,Som at være der selv", ifølge en reklametekst. Det ser da også ud til, at tilskuerne til de levende billeder intenst lever med i denne formidlingsform, så intenst, at hele landets befolkning på een og samme tid kan springe op af stolen i national begejstring ved en målscoring på TV skærmen. Billederne ,,ryger lige ind“ og deres dramatiske effekt synes uden videre at påvirke følelseslivet. Deri består deres ,,force“. Savnet af analytisk eftertanke er imidlertid blevet afhjulpet ved hjælp af ,,slow-motion“ og ,stop-motion“ teknikken. Det er umuligt for øjet, at analysere de faktiske bevægelser, hvorfor disse kunstgreb til „frosne“" billeder svarende til fotografiet er nødvendige. Det interessante perspektiv heri er, at man kan betragte vistnok alle idrætslige billedfremstillinger lige fra tidernes morgen som sådanne ,,frosne“ billeder. Tænk på Diskoskasteren af Myron: En marmor (oprindelig bronze) skulptur af en atlet frosset midt i sin bevægelse.

Tag lærebøgerne i gymnastik gennem tiden, hvor trangen til billedfremstilling altid har været påtrængende, og bemærk, hvorledes tegningerne egentlig er film i ,,stop-motion“" (s. 154).

Tegningernes rækkefølge viser en stigende abstraktion fra naturalistisk menneskefremstilling til en bølgelinie, hvilket antyder, at essensen i idræt er ren bevægelse, ligesom film. Forbindelsen til følelseslivet ligger åbenbar allerede i sproget: Man bliver „,bevæget" af visse begivenheder, hvad enten man forholder kroppen i ro eller ej. Bevægelsens medium er de levende billeder, mens analyse af bevægelsen kræver tekniske indgreb. Tag filmen „Øvelser på gulv“, en Pondus film fra Den Danske Bank, som præsenteres således: ,,Filmen udnytter til fulde den filmiske teknik, slow-motion, frysebilleder, kontinuerlig forlæns og baglæns bevægelse illustrerer vigtige detaljer i de grundlæggende øvelser."

Når man beskæftiger sig med idrætshistorie falder det straks i øjnene, hvor bredt fænomenet idræt kan anskues. Historikere stammer ofte fra ,den lærde republik" og er traditionelt et bogens folk. Følgelig graver de sig ned i de skriftlige kilder, skriver afhandlinger og, når et bredere dannet publikum skal informeres, udgiver mere eller mindre let læselige bøger. Tendensen bliver følgelig, at hovedvægten i historien lægges på de områder, hvor der findes skriftligt materiale. For idrætshistoriens vedkommende vil idrættens sociale, politiske og personorienterede aspekter således være oplagte indgangsvinkler for historikerne. Ikke uden grund kan man sige om historien: „Af ord er du kommen, til ord skal du blive ...."

Dermed lukker kredsen sig endnu engang - historien opstår i den verbale kulturkreds og forbliver der. 
Hvis man ønsker at bryde denne cirkel og nå ud til andre kredse, må der en fundamental ændring til.

Hvilke kredse kunne idrætshistorie tænkes henvendt til? Ja, idrætsudøvere i al almindelighed ville være en nærliggende mulighed, og hvis man vælger den, må man indrette sig derefter. Hermed kommer de ikke-verbale formidlingsformer naturligt ind i billedet. Det betyder selvfølgelig ikke, at idrætsudøverne i særlig grad anses for at være hverken hel- eller halvanalfabeter, men at, fordi de er så mange, en del vil være ikke-bogligt orienterede, og at idræt i sig selv i særlig grad er visuel. Dertil kommer den banale konstatering, at jo lavere interesseniveau et emne befinder sig på i præsentationsfasen, jo

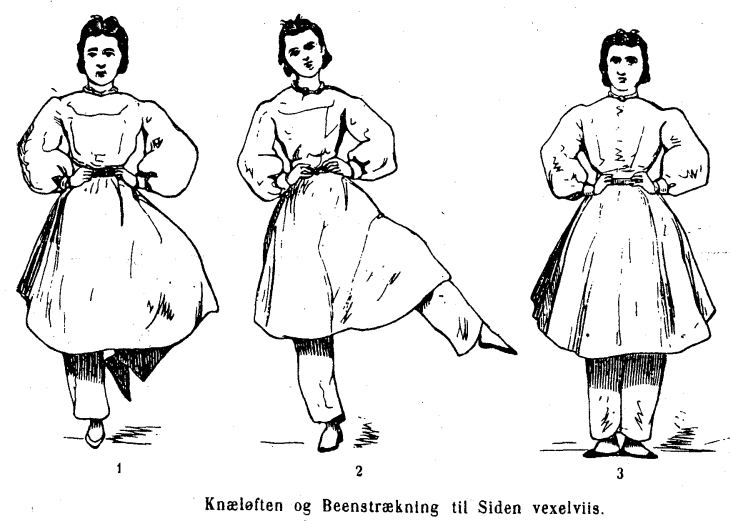

Skiften mellem staaende Hælhæuning og halv Knæbøjning med Hoftefatning (1-4) og Armstrækning opad. (5-8).
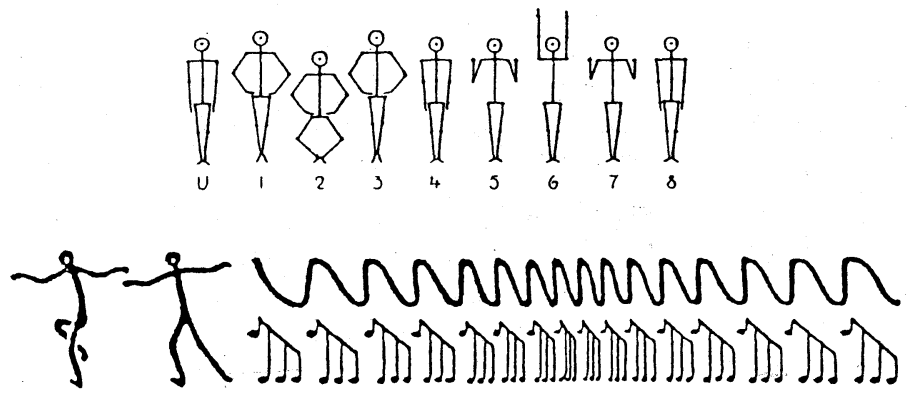

De 3 tegninger kan hver for sig synes interessante og oplysende, men sat $i$ sammenhæng som her kan de illustrere en historisk udvikling $i$ synet på kroppen og gymnastikken. 
ringere anstrengelse fordres ved tilegnelsen. Igen byder de ikke-verbale visuelle formidlingsformer på fordele.

Begiver man sig ind $\mathrm{i}$ idrætshistorien fra denne vinkel, bliver det hurtigt klart, at man har brug for andre kilder end de traditionelle, og at det bliver en anden historieskrivning end bøgernes. Vægten ligger et eller andet sted i det synlige, kroppen, bevægelserne, tøjet, redskaberne, lokalerne osv.

Valget af medium er således bestemt af valget af modtagergruppe, og disse valg bestemmer igen arten af historieskrivning. Det vil almindeligvis synes historikerne bagvendt, eftersom de $\mathrm{i}$ deres arbejde oftest tager udgangspunkt i sig selv og den problemstilling, de finder betydningsfuld eller interessant. Til gengæld må de ofte se bort fra, om det interesserer en større kreds - og hvilken.

Den visuelt orienterede historiker har mulighed for at få en større kreds og nye målgrupper $\mathrm{i}$ tale, men må på sin side indrette problemstillingen derefter. De visuelle formidlingsformer, der byder sig til, er mange. Nogle er dyrere, andre billigere end den traditionelle bog. Nogle eksempler:

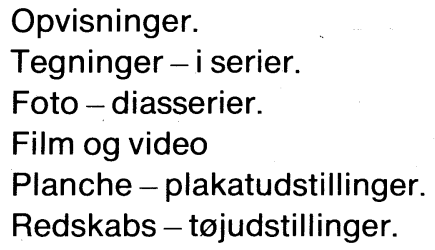

Det er imidlertid ikke gjort med at fremstille idrætshistorie i denne eller hin visuelle form. Den skal også ses, hvorfor der må fremskaffes kanaler og lejligheder, hvor kontakten til målgruppen kan finde sted. Her er igen flere muligheder: Fagpressen, særtryk, idrætshaller, foreningslokaler, skoler og andre steder, hvor idrætsudøverne kommer $i$ anden anledning. Hele arbejdet med at formidle denne form for visuelt fremstillet idrætshistorie kunne slås sammen under en hat - et idrætshistorisk museumscenter - en tanke, der i øvrigt for tiden arbejdes med fra flere sider.

Som nævnt er der her tale om en anden form for historieskrivning end den lærde, der i så høj grad er fastbundet til skriften. Det betyder imidlertid ikke, at visuel historie ikke skal være seriøs. Der er behov for en dybtgående forskning i dette kildeområde, som alt for længe har været negligeret af historikerne. Det arbejde der er blevet udført skyldes amatører og lærere, som har savnet idrætshistorisk fremstilling, et arbejde, som ikke skal forklejnes, men som skal udvides og uddybes.

Som endemål for en sådan visuel idrætshistorisk formidling til den brede kreds af idrætsudøvere kunne man ønske sig, at idrætten igen blev et 
kulturcenter i samfundet, at ,,kød“" og ,,Ånd“" fandt sammen på idrætspladsen, som i klassisk tid. Måske flere kunstnere så også ville få øje på idrætten.

Sådanne visioner er det jo behageligt at pusle med, men de kan også give et nyttigt sigtepunkt ved begyndelsen af et stort arbejde, og selvom historikeren arbejder med fortiden bør han tænke på, at han arbejder for fremtiden.

Historie er jo ikke kun en dødedans. 